\title{
HARMONICZNE PRĄDU W LINIACH I URZĄDZENIACH ELEKTRYCZNYCH ZASILAJĄCYCH ODBIORCÓW KOLEJOWYCH
}

\begin{abstract}
W artykule przedstawiono funkcjonujące definicje, które wynikają z obowiązujących unormowań prawnych oraz technicznych. Przedstawiono również elementy układu prostowniczego podstacji, które podczas pracy awaryjnej powodują nieprawidłowości dotyczące występujących zaburzeń wprowadzanych do sieci zasilania oraz do odbiorców zasilanych z urządzeń podstacji trakcyjnej. Wymieniono poziomy napięcia zasilania w liniach zasilających podstacje trakcyjne. Wymieniono również niekorzystne oddziaływania harmonicznych na pracę wybranych odbiorników energii elektrycznej oraz sposoby ich zmniejszenia. Opisano wpływ harmonicznych na wybrane elementy takie jak: transformatory, kondensatory, generatory i silniki. Zostały również przedstawione podstawowe wymagania dotyczące jakości energii elektrycznej w urządzeniach PKP Polskie Linie Kolejowe S.A. oraz wymieniono typy podstawowych odbiorów kolejowych, które przede wszystkim służą do zapewnienia bezpiecznego prowadzenia ruchu pociągów.
\end{abstract}

Słowa kluczowe: podstacja trakcyjna, harmoniczne prądu, zespół prostownikowy

\section{Wprowadzenie}

Odbiorniki nieliniowe są źródłem obniżenia jakości energii elektrycznej, ponieważ pobierany przez nie prąd z sieci nie jest sinusoidalny. Wyższe harmoniczne są przyczyną dużych strat energetycznych. Minimalizowanie prądów wyższych harmonicznych jest zagadnieniem, które jest przedmiotem wielu prac badawczych w różnych ośrodkach całego świata. Wprowadzane są coraz bardziej restrykcyjne normy, które wymuszają u dostawców energii elektrycznej minimalizowanie negatywnego wpływu wyższych harmonicznych.

W celu określenia wartości zniekształceń napięciowych, konieczna jest analiza zniekształceń prądowych oraz impedancji zwarciowej układu. Powstające zniekształcenia napięciowe zależne są od parametrów układu zasilania, a znie-

\footnotetext{
${ }^{1}$ Robert Żelazny, PKP Polskie Linie Kolejowe S.A. oraz Politechnika Częstochowska Wydział Elektryczny, email: Robert1980@interia.eu
} 
kształcenia prądowe są zależne od indywidualnych cech danego urządzenia. Podstacje trakcyjne są jednym $\mathrm{z}$ większych odbiorców podłączonych do systemu elektroenergetycznego. Kolejowy system elektroenergetyczny przede wszystkim ma za zadanie zasilanie wszystkich pojazdów trakcyjnych napięciem znamionowym o wartości $3000 \mathrm{~V}$ prądu stałego. Dodatkowo z podstacji trakcyjnej zasilane są odbiorniki PKP PLK S.A., które są niezbędne do bezpiecznego prowadzenia ruchu pociągów $[1,2,3]$ oraz inni odbiorcy podłączeni do linii potrzeb nietrakcyjnych. Energia elektryczna jest towarem, który można dostarczać innym odbiorcom, dlatego poza atrakcyjną ceną musi spełniać określone wymagania pod względem jakości $[4,5,6,7]$. Wymagania te dotyczą zarówno energetyki zawodowej, jak również energetyki kolejowej. Dopuszczalna wartość odkształcenia prądu zależy od grupy przyłączeniowej, do jakiej dany odbiorca jest zakwalifikowany $[8,9]$.

\section{Definicje, przepisy, dyrektywy i normy dotyczące harmonicznych prądu i napięcia w sieci zasilającej oraz ich klasyfikacje}

Wymagania dotyczące poziomów zawartości harmonicznych prądu są znormalizowane, lecz dotyczy to tylko odbiorników przyłączonych do sieci niskiego napięcia. Odbiorniki w sieciach niskiego napięcia są podzielone na dwa przedziały dotyczące znamionowego prądu fazowego: mniejsze lub równe od 16 A [6] oraz większe od 16 A i mniejsze lub równe od 75 A [7]. Na podstawie norm [6, 7] operatorzy systemu elektroenergetycznego opracowują instrukcje, w których są zamieszczone dane dotyczące dopuszczalnych zawartości harmonicznych jako wartości obligatoryjne $[4,10]$. Sieci o napięciu znamionowym wyższym od $1 \mathrm{kV}$ nie są objęte unormowaniami dotyczącymi dopuszczalnych poziomów generacji harmonicznych. W celu obliczenia poziomów zawartości harmonicznych w odkształconych przebiegach napięć lub prądów wprowadzono pojęcie współczynnika THD (ang. Total Harmonic Distortion). Współczynnik THD oznacza wartość całkowitej zawartości harmonicznych i jest zdefiniowany dla zawartości harmonicznych prądu. Dla porównania zawartości harmonicznych oraz współczynnika odkształcenia prądu $\mathrm{THD}_{\mathrm{I}}$ można posłużyć się postanowieniami normy IEEE [11].

\section{Klasyfikacja harmonicznych}

Wyższe harmoniczne mogą występować zarówno w przebiegach prądów jak i przebiegach napięć. Ze względu na częstotliwość składowych analizowanego przebiegu, w odniesieniu do częstotliwości podstawowej harmonicznej, harmoniczne dzielimy na: 
- Interharmoniczne, które definiuje się jako składowe o rzędach nie będących całkowitą krotnością częstotliwości podstawowej harmonicznej, mogące pojawiać się jako częstotliwości dyskretne lub jako szerokopasmowe spektrum. Interharmoniczne powstają w wyniku szybkich zmian prądu w urządzeniach. Wartość interharmonicznych zwiększa się na skutek wzrostu zastosowań przemienników częstotliwości i podobnych urządzeń sterujących. W określonych przypadkach interharmoniczne, niekiedy nawet o małych wartościach, powodują powstanie migotania światła lub powodują znaczne zakłócenia w pracy układów sterowania częstotliwości akustycznej [12].

- Subharmoniczne, które definiuje się jako składowe o częstotliwości niższej od podstawowej harmonicznej. Przyczyną występowania subharmonicznych jest praca odbiorników nieliniowych, takich jak np. falowniki, piece indukcyjne oraz odbiorników charakteryzujących się dużymi zmianami (w czasie) pobieranej mocy, np. pieców łukowych.

W układach zawierających elementy przekształtnikowe można dodatkowo rozróżnić dwie grupy:

- harmoniczne charakterystyczne, które występują w prądach przekształtnika w idealnych warunkach pracy.

- harmoniczne niecharakterystyczne, które występują w prądach przekształtnika w rzeczywistych warunkach pracy, gdzie obecność nie wynika z liczby pulsów przekształtnika, np. 8 harmoniczna w przekształtniku 12-pulsowym.

\section{3. Źródła oraz klasyfikacja skutków obecności wyższych harmonicznych}

Wyższe harmoniczne pojawiają się w wyniku występowania w sieci urządzeń, które powodują odkształcenia przebiegu prądu (tab. 1). Urządzenia, o których mowa to:

- urządzenia elektroniczne i energoelektroniczne.

- urządzenia łukowe: piece łukowe, urządzenia spawalnicze, wyładowcze źródła światła.

- urządzenia z rdzeniami magnetycznymi: silniki, transformatory.

Podstacje trakcyjne jako element systemu elektroenergetycznego są zbudowane w taki sposób, aby poprzez linie zasilające o napięciu 15, 20, 30 lub $110 \mathrm{kV}$ i urządzenia podstacji trakcyjnych zasilać (przez sieć trakcyjną) pojazdy trakcyjne napięciem $3000 \mathrm{~V}$ prądu stałego. Dodatkowo system ten w części przemiennoprądowej służy do zasilania odbiorów nietrakcyjnych przez linię potrzeb nietrakcyjnych (LPN). W podstacjach trakcyjnych zamontowane urządzenia mające wpływ na jakość energii elektrycznej prądu stałego oraz przemiennego to zespół prostownikowy współpracujący z dławikiem (rys. 1 i 2). 


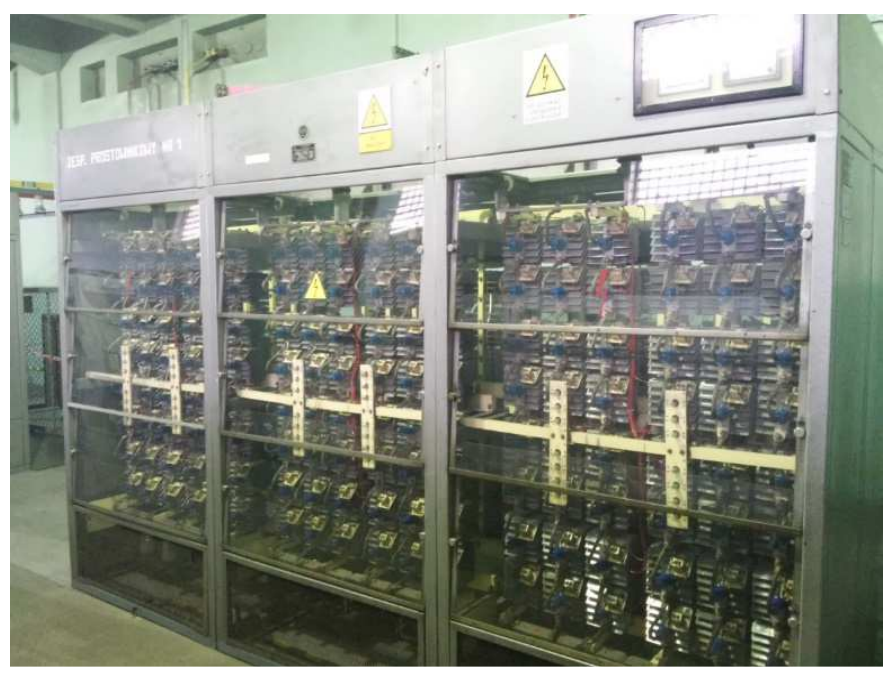

Rys. 1. Zespół prostownikowy typu PK 17/3,3-3

Fig. 1. PK 17 / 3,3-3 rectifier unit

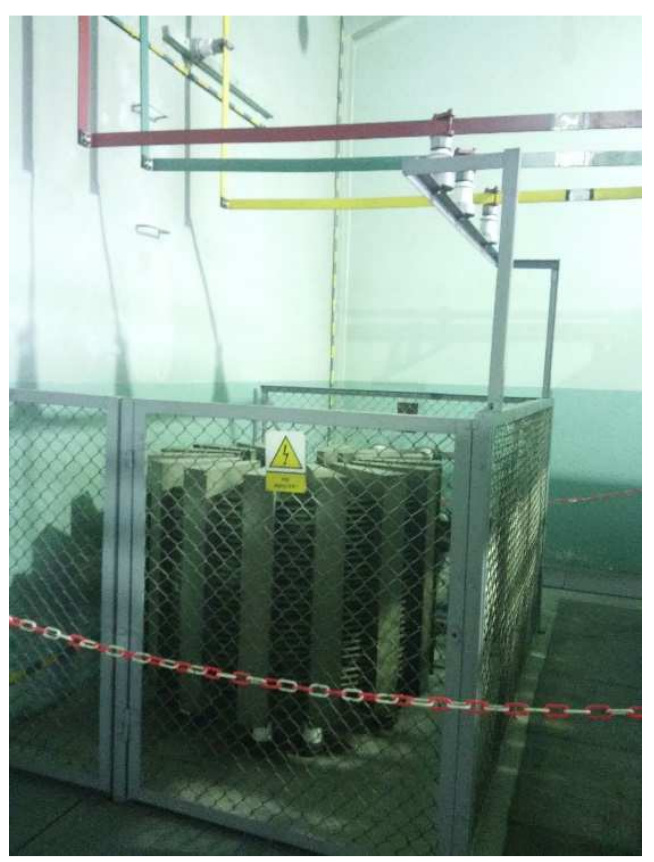

Rys. 2. Dławik typu XLEB4 120

Fig 2. Choke type XLEB4 120 
Tabela 1. Klasyfikacja skutków występowania harmonicznych w liniach i urządzeniach elektrycznych

Table 1. Classification of the effects of harmonic appearance in lines and electrical devices

\begin{tabular}{|c|c|c|}
\hline Klasyfikacja & Skutki & $\begin{array}{l}\text { Opis wpływu harmonicznych na pracę } \\
\text { odbiorników energii elektrycznej }\end{array}$ \\
\hline \multirow[b]{2}{*}{$\begin{array}{l}\text { Charakter } \\
\text { fizyczny } \\
\text { odkształconego } \\
\text { przebiegu }\end{array}$} & Napięciowe & $\begin{array}{l}\text { Wpływ poprzez wartość odkształconego } \\
\text { przebiegu napięcia. }\end{array}$ \\
\hline & Prądowe & $\begin{array}{l}\text { Harmoniczne prądu są powodem wzrostu } \\
\text { temperatury w urządzeniach i skrócenia } \\
\text { ich żywotności. Wpływ poprzez wartość } \\
\text { chwilową lub uśrednioną w trakcie prze- } \\
\text { pływu prądu np. poprzez wzrost tempera- } \\
\text { tury maszyn, wzrost strat w liniach zasila- } \\
\text { jących, itp. }\end{array}$ \\
\hline \multirow{2}{*}{$\begin{array}{c}\text { Czas } \\
\text { występowania }\end{array}$} & $\begin{array}{l}\text { Chwilowe } \\
\text { lub o charakterze } \\
\text { natychmiastowym }\end{array}$ & $\begin{array}{l}\text { Są to wadliwe działania urządzeń lub ich } \\
\text { uszkodzenia. Przykładowe urządzenia to } \\
\text { urządzenia pomiarowe, zabezpieczające, } \\
\text { sterujące, sprzęt elektroniczny oraz sprzęt } \\
\text { komputerowy, itp. }\end{array}$ \\
\hline & Długotrwałe & $\begin{array}{l}\text { Podstawowy wpływ jest związany z długo- } \\
\text { trwałym oddziaływaniem temperatury na } \\
\text { urządzenia. W efekcie tego działania nastę- } \\
\text { puje przyspieszony proces starzenia się } \\
\text { izolacji i następnie skrócenie żywotności } \\
\text { danego urządzenia. } \\
\end{array}$ \\
\hline \multirow{2}{*}{$\begin{array}{c}\text { Miejsca } \\
\text { występowania }\end{array}$} & $\begin{array}{l}\text { W liniach zasilają- } \\
\text { cych oraz rozdziel- } \\
\text { niach }\end{array}$ & $\begin{array}{c}\text { W liniach średniego napięcia może poja- } \\
\text { wić się zjawisko rezonansu napięcia co po- } \\
\text { woduje większe odkształcenia napięcia } \\
\text { (bezpośredni wpływ na pracę transforma- } \\
\text { torów) } \\
\end{array}$ \\
\hline & $\begin{array}{l}\text { W sprzęcie oraz } \\
\text { w urządzeniach } \\
\text { elektrycznych }\end{array}$ & $\begin{array}{l}\text { Dla linii nN napięcia harmoniczne prądu } \\
\text { powodują bezpośredni wpływ na pracę sil- } \\
\text { ników oraz kondensatorów, co jest przy- } \\
\text { czyną wielu uszkodzeń i awarii }\end{array}$ \\
\hline $\begin{array}{l}\text { Składowe } \\
\text { odkształconych } \\
\text { przebiegów }\end{array}$ & Składowa stała & $\begin{array}{l}\text { Obecnie wpływ zastosowanych prostowni- } \\
\text { ków oraz elektronicznego sprzętu w go- } \\
\text { spodarstwach domowych i przemyśle } \\
\text { może być powodem występowania składo- } \\
\text { wej stałej w napięciu. Efektem tego może } \\
\text { być doprowadzenie do nasycenia rdzeni } \\
\text { transformatorów. Może również spowodo- } \\
\text { wać zakłócenia w pracy układów pomiaro- } \\
\text { wych oraz zabezpieczeń. }\end{array}$ \\
\hline
\end{tabular}




\section{Jakość energii elektrycznej na podstacji trakcyjnej (PT)}

Urządzenia zainstalowane na podstacji trakcyjnej mają duży wpływ na jakość energii elektrycznej. Standardy jakościowe podmiotów zaliczanych do grup przyłączeniowych I i II dotyczą w przypadku podstacji trakcyjnych zasilanych napięciem $110 \mathrm{kV}$ z transformacją jednostopniową $110 / 3 \mathrm{kV}$. Standardy jakościowe podmiotów zaliczanych do grup przyłączeniowych III - V dotyczą podstacji trakcyjnych zasilanych napięciem 15, 20 i $30 \mathrm{kV}$. Zamontowane w podstacji trakcyjnej zespoły prostownikowe w rozdzielni prądu stałego są elementami nieliniowymi dużej mocy (rys. 3), które pobierają za pomocą linii zasilających prąd odkształcony od dostawcy energii elektrycznej. Pobierany prąd powoduje występowanie zjawiska odkształcenia napięcia na liniach zasilających.

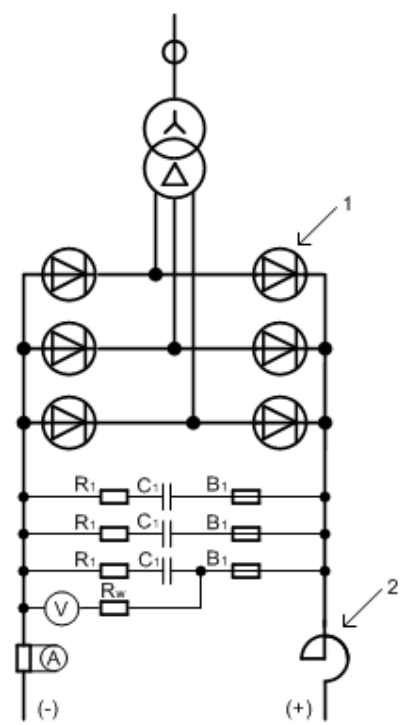

1 - dioda D200/1200,

2 - dławik katodowy,

$\mathrm{C} 1-4 \mu \mathrm{F}$,

$\mathrm{R} 1-10 \Omega$

B1 - (WBT - 3/10, 3kV, 10A),

C1, R1, B1 - tworzą zabezpieczenie od przepięć łączeniowych i atmosferycznych prostownika.

Rys. 3. Schemat obwodu głównego zespołu prostownikowego PK-17/3,3-3

Fig 3. Diagram of the circuit of the main rectifier unit PK17/3,3-3

Zjawisko to powoduje pogorszenie parametrów energii elektrycznej szczególnie, kiedy dodatkowy odbiorca jest podłączony do tej samej linii zasilającej lub szyn zbiorczych rozdzielni średniego napięcia (dotyczy grup przyłączeniowych III - V badanej podstacji). Znaczący wpływ na jakość energii elektrycznej ma wartość mocy zwarciowej na szynach rozdzielni prądu przemiennego, zasilanego przez dostawcę energii elektrycznej oraz typ zastosowanych zespołów prostownikowych. Widmo harmonicznych prądu zespołów prostownikowych zależy od liczby pulsacji (1), które można obliczyć wg wzoru: 


$$
n=m \cdot p \pm 1
$$

gdzie: $\mathrm{n}$ - rząd harmonicznej prądu,

$m=1,2,3$ (kolejne liczby naturalne),

$p$ - liczba pulsacji zespołu prostownikowego,

\section{Problemy wynikające z dużego poziomu zawartości wyższych harmonicznych $i$ ich wpływ na odbiorniki energii}

\subsection{Transformatory}

Transformatory znacznie doświadczają skutków oddziaływania wyższych harmonicznych, ponieważ oprócz zakłóceń akustycznych, występuje tam wzrost strat mocy w rdzeniu. Straty te są przede wszystkim związane z histerezą magnetyczną i zwiększają się proporcjonalnie do częstotliwości, a straty związane z prądami wirowymi zwiększają się proporcjonalnie do kwadratu częstotliwości. Następną kwestią są straty w uzwojeniach, które są następstwem wzrostu wartości skutecznej prądu oraz zwiększonej rezystancji, co jest związane z efektem naskórkowości. W wyniku powyższych negatywnych wpływów na izolację uzwojeń transformatora, dochodzi do podwyższenia temperatury, a w efekcie skrócenie żywotności transformatorów. Nie bez znaczenia jest obecność składowej stałej prądu, co jest efektem podłączenia prostowników lub innych odbiorników elektronicznych jako obciążenia transformatorów. W wyniku tego następuje nasycenie rdzenia transformatora i następnie dalszy wzrost odkształcenia przebiegu prądu. Inne przyczyny strat mocy $\mathrm{w}$ transformatorach, to połączone $\mathrm{w}$ trójkąt uzwojenia stanowiące obwód zwarty dla prądów harmonicznych rzędu trzeciego i rzędów będących wielokrotnością trzech.

Mając na uwadze wyżej wymienione negatywne zjawiska, projektanci i producenci transformatorów są zmuszeni do projektowania oraz wykonania takich transformatorów, które już mają zawarte wszystkie zmiany konstrukcyjne w celu zmniejszenia strat.

W USA i Kanadzie wprowadzono inny sposób oznaczania transformatorów o zmniejszonych stratach mocy, które są przystosowane konstrukcyjnie do współpracy $\mathrm{z}$ odbiornikami o charakterystyce nieliniowej. Charakteryzują się one zwiększonymi zdolnościami akumulacji ciepła w porównaniu $\mathrm{z}$ typowymi jednostkami takiej samej mocy znamionowej, ponieważ zastosowano w nich zmiany konstrukcyjne powodujące zwiększoną redukcję strat mocy. Transformatory te są oznaczone symbolem „K” wraz z liczbą ze znormalizowanego szeregu: 4, 9, 13, 20, 30, 40 i 50 [13] oraz stosowane do różnego rodzaju obciążenia np.:

- K-4 - spawarki, zgrzewarki, urządzenia do nagrzewania indukcyjnego,

- K-13 - instalacje stosowane w biurowcach, szkołach oraz w szpitalach,

- K-20 - obwody w sieciach telekomunikacyjnych oraz do przesyłania danych. 


\subsection{Kondensatory}

Kondensatory są elementami, które w bardzo dużym stopniu doświadczają skutków pracy w czasie, gdy przebieg sinusoidy energii elektrycznej jest odkształcony. Producenci podają na tabliczkach znamionowych dopuszczalne współczynniki przeciążeniowe, które określają krotność ich wartości znamionowych. Wyznaczają one dla kondensatorów dopuszczalny zakres pracy, który w przypadku ich przekroczenia powoduje znaczące skrócenie ich żywotności. Wzrost zawartości wyższych harmonicznych może być powodem zwiększenia wartości szczytowej napięcia, która negatywnie wpływa na izolację kondensatorów. Może ona w konsekwencji spowodować częściowe wyładowanie w dielektryku i zwarcie między foliami izolacyjnymi. Takie problemy występujące $\mathrm{w}$ kondensatorach i w większości mają charakter prądowy. Harmoniczne obecne w przebiegach napięcia powodują przepływ dodatkowych prądów, które mogą rosnąć wraz ze wzrostem rzędu harmonicznej. W bateriach kondensatorów, przy znacznym przepływie prądu, występują negatywne zjawiska w postaci zwiększenia strat mocy, a w ekstremalnych przypadkach dochodzi do przepalenia bezpieczników. Takie zjawiska powodują przyspieszenie procesu starzenia i w konsekwencji znaczne skrócenie żywotności kondensatorów.

\subsection{Generatory oraz silniki}

Wyższe harmoniczne napięcia i prądu w maszynach synchronicznych i asynchronicznych powodują zwiększenie strat mocy, co skutkuje zwiększeniem temperatury pracy tych maszyn. Źródłem strat są uzwojenia maszyny oraz jej rdzeń, co w efekcie powoduje wzrost temperatury. Konsekwencją wzrostu temperatury są negatywne skutki w postaci pogorszenia parametrów izolacji, co w przypadku długotrwałego występowania powoduje skrócenie żywotności maszyny. W silnikach, obecność wyższych harmonicznych powoduje dodatkowe oscylacje momentu elektromagnetycznego wytwarzanego przez silnik. Oscylacje momentu są źródłem drgań, mogących powodować mechaniczne uszkodzenia silnika oraz napędzanej maszyny. Obecność wyższych harmonicznych powoduje w silnikach powstawanie napięć wałowych i przepływ prądów łożyskowych, prowadzących do szybszego zużycia i awarii łożysk silnika oraz maszyny przez silnik napędzanej.

\section{Metody ograniczania negatywnego wpływu wyższych harmonicznych na urządzenia}

a) Metody ograniczania negatywnego wpływu prądów z przebiegami odkształconymi na transformatory to: 
- przewymiarowanie uzwojeń połączonych w trójkąt i przewodu neutralnego przy połączeniu uzwojeń w gwiazdę ze względu na obecność harmonicznych rzędu trzeciego i rzędów będących wielokrotnością trzech (do $200 \%$ przekroju przewodów fazowych) [14],

- takie projektowanie rdzeni magnetycznych, aby w znamionowym punkcie pracy uzyskać odpowiednią wartość strumienia magnetycznego (poniżej kolana charakterystyki magnesowania). Uzyskuje się to między innymi poprzez stosowanie rdzeni z żelaza o odpowiedniej jakości i o odpowiednim przekroju poprzecznym [13],

- wykonywanie uzwojeń transformatorów przewodami równoległymi lub $\mathrm{z}$ folii (uzwojenia dolnego napięcia) w celu redukcji zjawiska naskórkowości i zmniejszenia strat wiroprądowych [13],

- stosowanie ekranów elektrostatycznych pomiędzy uzwojeniem pierwotnym a wtórnym,

b) Metody ograniczania negatywnego wpływu prądów z przebiegami odkształconymi na kondensatory to:

- eliminowanie przewodu neutralnego dla baterii połączonych w gwiazdę. Ma to na celu wyeliminowanie obciążenia prądami harmonicznych rzędu trzeciego i rzędów będących wielokrotnością trzech.

- przebudowa urządzeń energetycznych w taki sposób, aby kondensatory i układy nieliniowe nie miały wspólnego transformatora,

- stosowanie dławików przeciwrezonansowych,

c) Metody zmniejszania powstawania odkształcenia przebiegu prądu w podstacjach trakcyjnych to:

- zastępowanie zastosowanych zespołów prostownikowych innymi, powodującymi mniejsze odkształcenie parametrów energii elektrycznej. Przykładowo: zespoły 6-cio pulsowe można zastąpić 12-sto pulsowymi.

- stosowanie filtrów.

d) Metody zmniejszania odkształcenia przebiegu prądu to:

- stosowanie filtrów aktywnych, które powodują zmianę przebiegu chwilowego prądu w czasie poprzez układ sterujący z przebiegu odkształconego na sinusoidalny. Filtry te są projektowane jako podłużne (szeregowe), poprzeczne (równoległe) oraz jako szeregowo-równoległe.

- stosowanie filtrów pasywnych rezonansowych nazywanych jako „rezonansowe filtry wyższych harmonicznych”. Filtry te są włączane poprzecznie do układu sieci. W skład filtru wchodzi kondensator oraz dławik. 


\section{Podsumowanie}

Zasilanie sieci trakcyjnej PKP Polskie Linie Kolejowe S.A. jest realizowane napięciem stałym o wartości $3000 \mathrm{~V}$. Transformacja napięcia przemiennego na napięcie stałe odbywa się poprzez transformator oraz zespół prostownikowy w podstacji trakcyjnej. W takich zespołach prostownikowych uzyskuje się napięcie wyprostowane z zawartością wyższych harmonicznych. Harmoniczne te przenoszą się do dostawcy energii elektrycznej poprzez linie zasilające podstację trakcyjną. Dodatkowo odbiorcy energii elektrycznej podłączeni do (LPN) linii potrzeb nietrakcyjnych z podstacji trakcyjnej również są narażeni na negatywny wpływ oddziaływania wyższych harmonicznych na swoje urządzenia. W celu zmniejszania negatywnego oddziaływania wyższych harmonicznych stosuje się wyżej opisane dławiki, filtry pasywne rezonansowe oraz aktywne. Działania te są niezbędne, aby współczynnik zawartości wyższych harmonicznych napięcia i prądu (THD) zawierał się w granicach obowiązujących norm. W celu zapewnienia bezpiecznego prowadzenia ruchu kolejowego należy spełnić wszystkie wymienione w artykule wymagania i podstawowe parametry jakości energii elektrycznej. Harmoniczne prądu, osiągając wartości przewyższające poziomy normatywne, mają bardzo negatywny wpływ na podstawowe elementy systemu energetycznego, które mogą spowodować zwiększenie ilości awarii oraz skrócić ich żywotność.

\section{Literatura}

[1] Opracowanie wymagań na zasilanie energią elektryczną urządzeń sterowania ruchem kolejowym. Praca CNTK nr 4034/10, Warszawa 2003.

[2] PN-EN 50121-2: 2004. Zastosowania kolejowe. Kompatybilność elektromagnetyczna. Część 2: Oddziaływanie systemu kolejowego na otoczenie.

[3] Standardy techniczne - szczegółowe warunki techniczne dla modernizacji lub budowy linii kolejowych do prędkości Vmax $\leq 200 \mathrm{~km} / \mathrm{h}$ (dla taboru konwencjonalnego) $/ 250 \mathrm{~km} / \mathrm{h}$ (dla taboru z wychylnym pudłem). Warszawa 2009.

[4] Hanzelka Z.: Jakość energii elektrycznej. Część 4. Wyższe harmoniczne napięć i prądów.

[5] Ustawa z dnia 10 kwietnia 1997r. z późniejszymi zmianami Prawo energetyczne Dz.U. z 2012r., poz. 1059. Z 2013r., poz. 984 i poz.1238, z 2014r., poz. 457, poz. 490, poz. 900 , poz. 942 , poz. 11010 , poz. 1662 oraz z 2015r. poz. 151, poz. 478 i poz. 942.

[6] PN - EN 61000-3-2: Kompatybilność elektromagnetyczna (EMC) - Część 3-2: Poziomy dopuszczalne - Poziomy dopuszczalne emisji harmonicznych prądu (fazowy prąd zasilający odbiornika $\leq 16 \mathrm{~A})$.

[7] PN-EN 61000-3-12: Kompatybilność elektromagnetyczna (EMC) - Część 3-12: Dopuszczalne poziomy - Dopuszczalne poziomy harmonicznych prądów powodowa- 
nych działaniem odbiorników, które mają być przyłączone do publicznej sieci zasilającej niskiego napięcia $\mathrm{z}$ fazowym prądem zasilającym odbiornika >16 A $\mathrm{i} \leq 75 \mathrm{~A}$.

[8] Rozporządzenie Ministra Gospodarki z 4 maja 2007 r. w sprawie szczegółowych zasad funkcjonowania systemu elektroenergetycznego (Dz. U. z 2007 r. Nr 93, poz. 623, z późn. zm.), s. 5665-5668.

[9] PN-IEC 60364: 2006-2009. Instalacje elektryczne w obiektach budowlanych.

[10] Instrukcja Ruchu i Eksploatacji Sieci Dystrybucyjnej (zatwierdzona decyzją Prezesa URE nr DRR-4321-29(5)/2013/MKo4 z dnia 10 września 2013 r.), s. 99-101.

[11] IEEE Recommended Practices and Requirements for Harmonic Control in Electrical Power Systems. AN-SI/IEEE Std 519-1992.

[12] PN-EN 50160:2010 Parametry napięcia zasilającego w publicznych sieciach elektroenergetycznych, s.13.

[13] „K-Factor Isolation Transformer” (AET-2009-AET_K13-Factor_400V_R1.pdf), www.aet.com.sg.

[14] Jagieła K., Rak J., Gała M., Kępiński M., Straty mocy w transformatorach energetycznych zasilających dużych odbiorców przemysłowych Energoenergetyka, nr 3(9)/2011.

\section{CURRENT HARMONICS IN POWER LINES AND DEVICES SUPPLING RAILWAY CONSUMERS}

\section{S u m m a r y}

The article presents functioning definitions, which result from applicable legal and technical regulations. Also shown elements of the substation rectification circuit, which during emergency operation cause irregularities occurring disturbances introduced to the power grid and to recipients supplied from traction substation devices. Power supply voltage levels in power lines for traction substations are listed. Also the adverse effects of harmonics on the operation of selected electric energy receivers and the ways of their reduction have been mentioned. Describes the effect of harmonics on selected components such as transformers, capacitors, generators and motors. Basic requirements concerning the quality of electric energy in PKP Polish Railway Lines S.A. were also presented and the types of basic railway trains were exchanged, which are primarily used to ensure safe operation of trains.

Keywords: Traction substation, current harmonics, rectifier unit

DOI: $10.7862 /$ re.2018.2

Tekst złożono w redakcji: grudzień 2017

Przyjęto do druku: grudzień 2017 
